\title{
Evaluation of Antioxidant Activity of Physalis Minima
}

\author{
SHWETA SINGH* and POONAM PRAKASH \\ Department of Chemistry, Sam Higginbottom Institute of Technology and Sciences \\ Allahabad- 211007, India \\ shwetasingh19oct@gmail.com
}

Received 15 December 2013 / Accepted 23 January 2014

\begin{abstract}
The present study aimed at evaluating the in vitro study of antioxidant activity of crude extracts (methanol, acetone, ethyl acetate and chloroform) of stem and leaves of physalis minima. The antioxidant activity was determined by two methods DPPH (1, 1-diphenyl- 2-picryl hydroxyl) assay and reducing power assay. The DPPH free radical scavenging activity of stem and leaves of physalis minima was determined at different concentration $(200 \mu \mathrm{g}, 400 \mu \mathrm{g}, 600 \mu \mathrm{g}$ and $800 \mu \mathrm{g})$. The entire tested sample showed lower scavenging activity than standard. The scavenging effect and reducing power of the eight extracts of the leaf and stem decreased in order of Methanol leaf extract $>$ Methanol stem extract $>$ Acetone leaf extract $>$ Ethyl acetate leaf extract $>$ Acetone stem extract $>$ Ethyl acetate stem extract $>$ Chloroform leaf extract $>$ Chloroform stem extract. Thus result clearly indicated that the methanolic extract of leaf of P.minima showed higher activity compared to other extracts of stem and leaves. Hence is effective in scavenging free radical and has the potential to be a powerful antioxidant.
\end{abstract}

Keywords: DPPH (1, 1-diphenyl-2-picryl hydroxyl) assay, Reducing power assay, Antioxidant activity

\section{Introduction}

In response to the increased popularity and greater demand for medicinal plants a number of conservation groups are recommending that wild medicinal plants be brought into cultivation $^{1}$. It produces various antioxidative compounds to counteract reactive oxygen species (ROS) in order to survive. The production of reactive oxygen species in organisms can have a role in cell communication processes and defense mechanisms. However, excessive production and accumulation of these products can cause a series of biochemical reactions that can generate various dis-orders on the cells ${ }^{2}$. Such natural antioxidants could prevent the formation of the above reactive species-related disorders in human beings without the use of synthetic compounds, which may be carcinogenic and harmful to the lungs and liver $^{3}$. A great number of natural medicinal plants have been tested for their antioxidant activities and results have shown that the raw extracts or isolated pure compounds from them were more effective antioxidants in vitro than BHT or vitamin $\mathrm{E}^{4}$ The majority of the antioxidant activity is due to the flavones, isoflavones, flavonoids, anthocyanin, catechins and isocatechins. A number of Solanum species have previously been 
investigated for their cytotoxicity, antioxidant and antiviral activities and treatment of protozoal infections. In vitro biological activities of most common medicinal plants ${ }^{5}$ and comparative study on antioxidant activity of different species of solanaceae family shows very significant result for medicinal value of this family.

The plant selected for the present study is physalis minima family solanaceae. Researchers isolated a new 13, 14- seco-16, 24-cyclosteroid, physalin L, along with known compounds, from Physalis minima ${ }^{6}$. Due to the large biological activities of these compounds, Physalis plants were used for centuries as medicinal herbs in the treatment of urinary and skin diseases, gonorrhea, ulcers, sores and as a vermicidal drug and recent studies have confirmed their therapeutic properties ${ }^{7}$. The present study was carried out in the Department of Chemistry, School of Basic Science (SHIATS), Allahabad, India.

\section{Experimental}

\section{Collection of plant material}

Whole plants of Physalis minima were uprooted and collected in polythene bags. The plants were washed in tap water and air dried. Stem and leaves were collected in separate paper covers and dried in shade for 20 days.

\section{Preparation of extracts}

The dried plant materials (stem and leaves) of P.minma were made to fine powder using homogenizer. The dried powders were extracted separately with continuous shaking for $24 \mathrm{~h}$ using solvents (ethyl acetate, acetone, chloroform and methanol). The extracts were filtered through Whatman no. 1 filter paper to remove all unextractable matters. The entire extracts were concentrated to dryness under reduced pressure and same method was repeated for 3 times. The dried condensed extracts of stem and leaves were stored in desiccators.

\section{Reagents}

$10 \mathrm{mg}$ of 1, 1-Diphenyl-2-picrylhydrazyl (DPPH) was dissolved in $100 \mathrm{~mL}$ of methanol solution, phosphate buffer $(0.2 \mathrm{M}, \mathrm{pH}$ 6.6), potassium ferricyanide (1\%), trichloroacetic acid (10\%) and ferric chloride (0.1\%) were prepared.

\section{Antioxidant Activity}

\section{Scavenging activity on DPPH radical}

The DPPH radical scavenging assay was elucidated as per literature method ${ }^{8}$. Different dilutions of extract (200, 400, 600 and $800 \mu \mathrm{g} / \mathrm{mL}$ ) were prepared. DPPH solution was also prepared by dissolving $10 \mathrm{mg}$ of DPPH in $100 \mathrm{~mL}$ methanol. Then, $1 \mathrm{~mL}$ of extract from each dilution was added into the test tube containing $2 \mathrm{~mL}$ of DPPH solution. Control was prepared by adding 1 $\mathrm{mL}$ of methanol to $2 \mathrm{~mL}$ of DPPH solution. Ascorbic Acid was used as standard. The mixture was shaken vigorously and was left to stand in the dark for $30 \mathrm{~min}$. The absorbance of the resulting solution was measured spectrophotometrically at $517 \mathrm{~nm}$. The scavenging activity of each extract on DPPH radical was calculated using the following equation:

\section{Calculation}

$$
\% \text { Scavenging DPPH free radical }=100 \times(1-\mathrm{AE} / \mathrm{AD})
$$

Where AE is absorbance of the solution, when extracts had been added at a particular level and AD is the absorbance of the DPPH solution without extract (control). 


\section{Reducing power assay}

Antioxidant activity by reducing power assay was elucidated as per literature method ${ }^{9}$. The reducing power of the test sample was determined by taking different concentration of the extract $(200,400,600$ and $800 \mu \mathrm{g} / \mathrm{mL}$ ) in $1 \mathrm{~mL}$ methanol. They were mixed with $2.5 \mathrm{~mL}$ of phosphate buffer and $2.5 \mathrm{~mL}$ of potassium ferric cyanide in test tubes. The mixtures were incubated for $20 \mathrm{~min}$ at 50 . At the end of the incubation $2.5 \mathrm{~mL}$ of tri-chloroacetic acid was added to the mixtures followed by centrifuging at $500 \mathrm{r} / \mathrm{min}$ for $10 \mathrm{~min}$. The upper layer $(2.5 \mathrm{~mL})$ was mixed in $2.5 \mathrm{~mL}$ distilled water and $0.5 \mathrm{~mL}$ of ferric chloride and the absorbance was measured at $700 \mathrm{~nm}$. The reducing power testes were run in triplicates.

\section{Statistical analysis for biochemical parameters}

The results presented are the means of three independent experiments. Values were expressed as Mean \pm S.D. ${ }^{10}$ Mean and S.D. was calculated with the help of microsoft excel 2007.

\section{Results and Discussion}

\section{$D P P H$ free radical scavenging activity}

The DPPH assay method was based on the reduction of DPPH, a stable free radical. The free radical DPPH with an odd electron gave a maximum absorption at $517 \mathrm{~nm}$ (purple colour) ${ }^{11-13}$. For the present study standard ascorbic acid was used ${ }^{14,11,15}$ (Table 1).

Table 1. The DPPH free radical scavenging activity of stem

\begin{tabular}{cccccc}
\hline \multirow{2}{*}{$\begin{array}{c}\text { Concentration } \\
\mu \mathrm{g} / \mathrm{mL}\end{array}$} & \multicolumn{5}{c}{ \% Inhibition of different extracts stem } \\
\cline { 2 - 6 } & $\begin{array}{c}\text { methanol } \\
\text { extract }\end{array}$ & $\begin{array}{c}\text { ethyl acetate } \\
\text { extract }\end{array}$ & $\begin{array}{c}\text { acetone } \\
\text { extract }\end{array}$ & $\begin{array}{c}\text { chloroform } \\
\text { extract }\end{array}$ & $\begin{array}{c}\text { ascorbic } \\
\text { acid }\end{array}$ \\
\hline 200 & 63.01 & 58.33 & 59.75 & 53.87 & 92.95 \\
400 & 65.62 & 64.73 & 64.22 & 55.42 & 93.68 \\
600 & 72.76 & 68.60 & 70.73 & 57.75 & 94.16 \\
800 & 76.02 & 71.71 & 72.76 & 59.11 & 94.65 \\
\hline
\end{tabular}

As mentioned in Table 1 Ascorbic acid showed highest \% inhibition at the concentration of $800 \mu \mathrm{g} / \mathrm{mL}$. Thus it indicated that \% inhibition increases with increasing concentration ${ }^{16}$. All the four extracts of stem and standard were compared by Figure 1 and it was found that all the extracts of stem had less \% inhibition than standard. Due to its higher \% inhibition ascorbic acid was used as standard ${ }^{17}$. Methanol extract of stem had highest $\%$ inhibition $76.02 \%$ followed by $72.76 \%$ of acetone extract, $71.71 \%$ of ethyl acetate extract and least $59.11 \%$ of chloroform extract of stem. Thus methanolic extract of stem was a good antioxidant than other extracts of stem ${ }^{5}$.

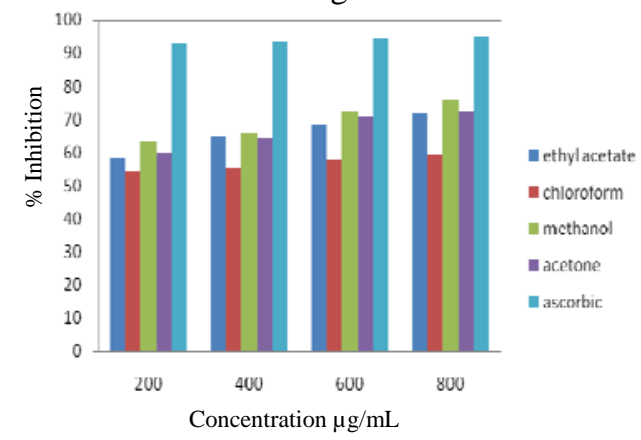

Figure 1. The DPPH free radical scavenging activity of stem 
Table 2. The DPPH free radical scavenging activity of leaves

\begin{tabular}{|c|c|c|c|c|c|}
\hline \multirow[b]{2}{*}{$\begin{array}{c}\text { Concentration } \\
\mu \mathrm{g} / \mathrm{mL}\end{array}$} & \multicolumn{5}{|c|}{ \% Inhibition of different extracts of leaves } \\
\hline & $\begin{array}{c}\text { methanol } \\
\text { extract }\end{array}$ & $\begin{array}{c}\text { ethyl acetate } \\
\text { extract }\end{array}$ & $\begin{array}{c}\text { acetone } \\
\text { extract }\end{array}$ & $\begin{array}{l}\text { chloroform } \\
\text { extract }\end{array}$ & $\begin{array}{c}\text { ascorbic } \\
\text { acid }\end{array}$ \\
\hline 200 & 68.78 & 59.10 & 61.54 & 50.70 & 92.95 \\
\hline 400 & 70.59 & 63.37 & 66.06 & 55.35 & 93.68 \\
\hline 600 & 72.85 & 64.73 & 69.23 & 58.14 & 94.16 \\
\hline 800 & 78.29 & 74.61 & 75.57 & 66.51 & 94.65 \\
\hline
\end{tabular}

On comparing all the four extracts of leaves (Figure 2) with ascorbic acid it was clear that it gave same result as of stem i.e. all extracts of leaves showed less activity than standard ascorbic acid and out of all extracts methanolic extract had highest radical scavenging activity $78.29 \%$ at $800 \mu \mathrm{g} / \mathrm{mL}$. When activity of stem and leaves extracts of P.minima was compared, it was found that leaves of Physalis minima were better antioxidant than stem. The antioxidant activity showed that methanolic leaves extract were able to reduce the stable radical DPPH to yellow DPPH-H upto $78.29 \%$ at concentration $800 \mu \mathrm{g} / \mathrm{mL}$ while stem showed $76.02 \%$ of inhibition. This result can be justify as DPPH radical scavenging assay showed that the aqueous extract of P.minima leaf had maximum inhibition ${ }^{18} 92.30 \%$. Furthermore the antioxidant activity was associated with this result is due to high level of polyphenol and vitamins A and C. ${ }^{19}$.

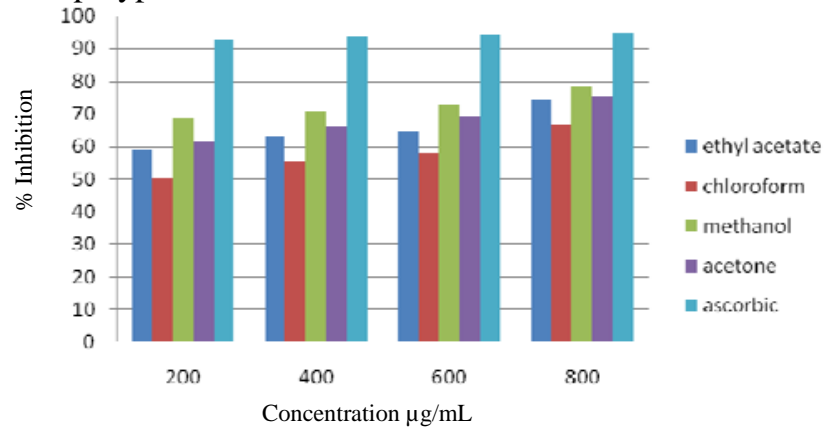

Figure 2. DPPH free radical scavenging activity of leaves

Thus result clearly indicates that the methanolic extract of leaf of P.minima showed higher activity compared to other extracts of stem and leaves. Hence was effective in scavenging free radical and had the potential to be a powerful antioxidant.

\section{Reducing power method}

The reducing power of acetone, ethyl acetate, chloroform and methanolic extracts of Physalis minima (family solanaceae) were determined by the literature method ${ }^{9}$. Increased absorbance of the reaction mixture indicated increase in reducing power ${ }^{20}$.

When all the four extract of stem of P.minima were compared with standard ascorbic acid (Table 3 and Figure 3) then it was found that all the test showed lower reducing power than standard, while among the extracts, methanolic stem extract showed higher reducing power. Thus it gave same result as DPPH method.

When all the four extracts of leaves were compared with standard ascorbic acid, it was found that all the test samples showed less reducing power activity than ascorbic acid. Among four extracts of leaves methanolic extract had highest reducing power while chloroform least. 
Table 3. Reducing power activity of stem

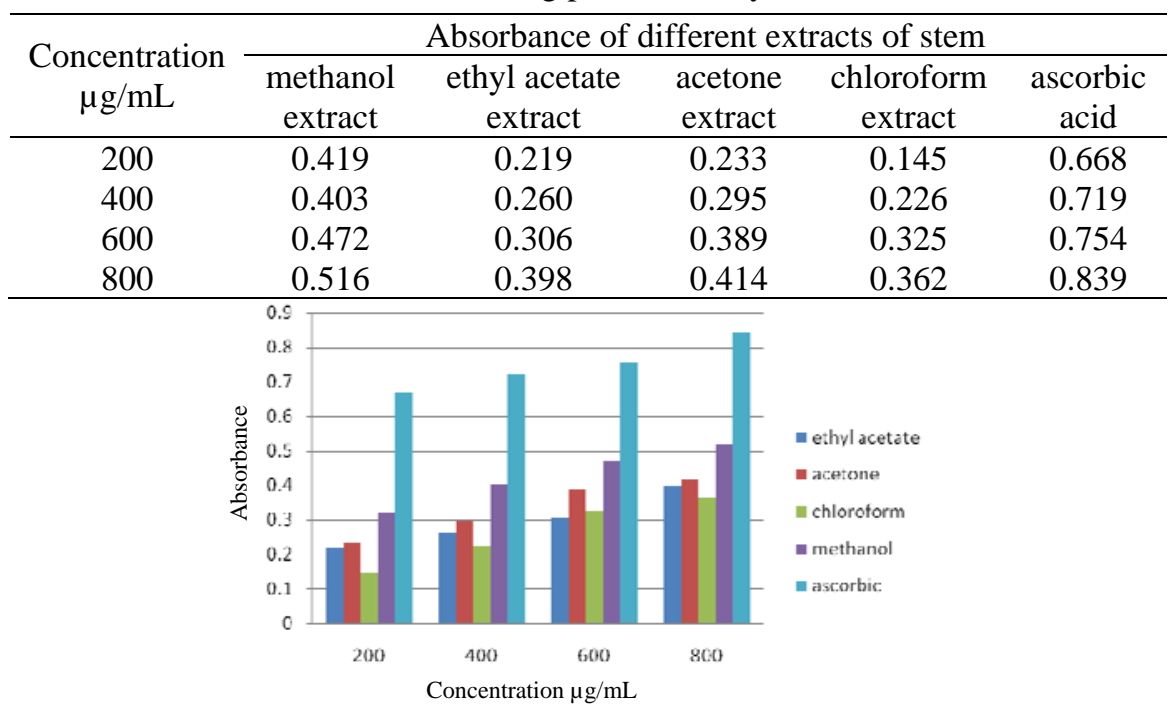

Figure 3. Reducing activity of stem

Thus the different concentration (200 $\mu \mathrm{g}, 400 \mu \mathrm{g}, 600 \mu \mathrm{g}$ and $800 \mu \mathrm{g}$ ) of stem and leaves of P.minima were taken. The absorbance was read at $700 \mathrm{~nm}$. The reducing power was found to be significant for stem (Table 3) and leaves (Table 4) when compared with standard ascorbic acid. From the Figure 3 and 4 methanolic extract of leaves at $800 \mu \mathrm{g} / \mathrm{mL}$ showed higher reducing activity 0.612 . It has agreement with the fact that increase in concentration reducing activity also increases ${ }^{20}$. But all the samples showed lower activity than standard.

Table 4. Reducing activity of extract of leaves

\begin{tabular}{|c|c|c|c|c|c|}
\hline \multirow[b]{2}{*}{$\begin{array}{c}\text { Concentration } \\
\mu \mathrm{g} / \mathrm{mL}\end{array}$} & \multicolumn{5}{|c|}{ Absorbance of different extracts of leaves } \\
\hline & $\begin{array}{c}\text { methanol } \\
\text { extract }\end{array}$ & $\begin{array}{c}\text { ethyl acetate } \\
\text { extract }\end{array}$ & $\begin{array}{l}\text { acetone } \\
\text { extract }\end{array}$ & $\begin{array}{c}\text { chloroform } \\
\text { extract }\end{array}$ & $\begin{array}{c}\text { ascorbic } \\
\text { acid }\end{array}$ \\
\hline 200 & 0.412 & 0.265 & 0.289 & 0.196 & 0.668 \\
\hline 400 & 0.467 & 0.300 & 0.318 & 0.248 & 0.719 \\
\hline 600 & 0.526 & 0.377 & 0.394 & 0.311 & 0.754 \\
\hline 800 & 0.612 & 0.426 & 0.456 & 0.390 & 0.839 \\
\hline 0.9 & & & & & \\
\hline 0.8 & & & & & \\
\hline 0.7 & & & & & \\
\hline 0.6 & & & & M ethyl acetate & \\
\hline 0.5 & & & & In acetone & \\
\hline 0.4 & & & & II chloroform & \\
\hline 0.3 & & & & Inethanol & \\
\hline 0.2 & & & & m ascorbic & \\
\hline 0.1 & & & & & \\
\hline & 200 & 600 & 800 & & \\
\hline
\end{tabular}

Figure 4. Reducing activity of extract of leaves 


\section{Conclusion}

The antioxidant activity was determined by two methods DPPH free radical scavenging and reducing power assay. The DPPH free radical scavenging activity of stem and leaves of Physalis minima was determined at different concentration $(200 \mu \mathrm{g} / \mathrm{mL}, 400 \mu \mathrm{g} / \mathrm{mL}, 600$ $\mu \mathrm{g} / \mathrm{mL}$ and $800 \mu \mathrm{g} / \mathrm{mL}$ ). It was compared with the standard ascorbic acid. The $\%$ inhibition of methanol, acetone, ethyl acetate and chloroform extracts of stem (Table 1) and leaves (Table 2) were determined. The entire tested sample showed lower scavenging activity than standard. Methanolic extract of leaves showed higher activity than other extracts.

The reducing power assay was also calculated and it was found that methanolic extract of Physalis minima leaf showed higher activity as it had the highest optical density or absorbance in turn increased absorbance of the reaction mixture indicated increase in reducing power. Thus reducing power is a significant indicator and supporting feature of antioxidant activity of extracts. Thus antioxidant activity of the eight extracts of the leaf and stem decreased in order of-

Methanol leaf extract $>$ Methanol stem extract $>$ Acetone leaf extract $>$ Ethyl acetate leaf extract $>$ Acetone stem extract $>$ Ethyl acetate stem extract $>$ Chloroform leaf extract $>$ Chloroform stem extract. Thus from above it is clear that Physalis minima will be applicable as a potential source of antioxidant for future researches.

\section{Acknowledgment}

First and foremost we bow down before "Almighty God" with solicits to express our deepest sense of gratitude to his blessing, mercy, faithfulness and thus enabling us to accomplish this venture. It is our immense pleasure to express profound sense of regard to the teaching and non teaching staff of our Department of Chemistry of SHIATS, for their kind support which helped us a lot to carry out our work. We are highly grateful to all of them without whose cooperation this work would not have been materialized.

\section{References}

1. $\quad$ Aqil F., Ahmed I. and Mehmood Z, Turk J Biol., 2006, 30(3), 177-183.

2. $\quad$ Migliore L and Coppedè F, Mutat Res., 2009, 31, 73-74.

3. Witschi H P, Food Chem Toxicol., 1986, 24(10-11), 1127-1130;

DOI:10.1016/0278-6915(86)90298-X

4. Pyo Y H, Lee T C, Logendrac L and Rosen R T, Food Chem., 2004, 85(1), 19-26; DOI:10.1016/S0308-8146(03)00294-2

5. Mahmood A, Mahmood A and Mahmood M, World Appl Sci J., 2012, 17(8), 1026-1032.

6. Sen G and Pathak H D, Phytochemistry, 1995, 39(5), 1245-1246;

DOI:10.1016/0031-9422(94)00736-D

7. Lan Y H, Chang F R, Pan M J, Wu C C, Wu S J, Chen S L, Wang S S, Wu M J and Wu Y C, Food Chem., 2009, 116(2), 462-469; DOI:10.1016/j.foodchem.2009.02.061

8. Chan E W C, Lim Y Y and Omar M, J Food Chem., 2007, 104(4), 1586-1593; DOi:10.1016/j.foodchem.2007.03.023

9. Yen G C and Duh P D, J Agric Food Chem., 1994, 42(3), 629 632; DOI:10.1021/jf00039a005

10. Khalighi S F, Ahvazi M, Yazdani D and Kashefi M, J Med Plants, 2012, 11(43). 41-53

11. Blois M S, Nature, 1958, 181, 1199-1200; DOI:10.1038/1811199a0

12. $\quad$ Lu Y and Foo L Y, Food Chem., 2000, 68(1), 81-85;

DOI:10.1016/S0308-8146(99)00167-3 
13. Zhu Q Y, Hackman R M, Ensunsa J L, Holt R R and Keen C L, J Agric Food Chem., 2002, 50(23), 6929-6934; DOI:10.1021/jf0206163

14. Kim J K, Noh J H, Lee S, Choi J S, Suh H, Chung H Y, Song Y O and Choi W C, Bull Korean Chem Soc., 2002, 23(5), 661- 662.

15. Sanchez M C, Larrauri J A and Saura C F, Food Res Int., 1999, 32(6), 407-412; DOI:10.1016/S0963-9969(99)00097-6

16. Molyneux P, .Songklanakarin J Sci Technol., 2004, 26(2), 211-219.

17. Srividya A R, Dhanabal P, Bavadia P, Vishnuvarthan V J and Kumar M N S, IJRAP., 2012, 3(3), 401-405.

18. Gupta V K and Sharma S K, Natural Product Radiance, 2006, 5(4), 326-334.

19. Puente L A, Claudia A Pinto Murioz, Castro E S and Cortes M, Food Res Int., 2011, 44(7), 1733-1740; DOI:10.1016/j.foodres.2010.09.034

20. Singhal M, Paul A, Singh H P, Dubey S K and Gaur K, J Chem Pharm Res., 2011, 3(3), 639-645. 